TABLE I-INCIDENCE OF OTITIS MEDIA IN CHILDREN, FINLAND, $1977-80^{\star}$

\begin{tabular}{|c|c|c|c|}
\hline \multirow[b]{2}{*}{$\begin{array}{l}\text { Otitis media with } \\
\text { pneumococci of }\end{array}$} & \multicolumn{2}{|c|}{$\begin{array}{l}\text { Incidence (per } 100 \text { ) among } \\
\text { children receiving }\end{array}$} & \multirow[b]{2}{*}{$\begin{array}{c}\% \\
\text { difference }\end{array}$} \\
\hline & $\begin{array}{l}\text { Pneumococcal } \\
\text { vaccine }\end{array}$ & $\begin{array}{l}\text { H. influenzae } \\
\text { vaccine }\end{array}$ & \\
\hline Vaccine serotype & $9 \cdot 6 \mathrm{t}$ & $14 \cdot 9$ & 36 \\
\hline $\begin{array}{l}\text { Vaccine serotype (except } \\
\text { group } 6 \text { ) } \\
\text { Non-vaccine serotype }\end{array}$ & $\begin{array}{l}5 \cdot 4 \\
1 \cdot 9\end{array}$ & $\begin{array}{r}12 \cdot 3 \\
3 \cdot 2\end{array}$ & $\begin{array}{l}56 \\
41\end{array}$ \\
\hline
\end{tabular}

*Adapted from Mäkelä's paper.

tCases per 100 children.

suggested by similar results in a previous trial of peumococcal vaccine. ${ }^{1}$ In that trial, pneumonia and bacteraemia caused by vaccine types was significantly less common in vaccinees than in controls (table II), but so were pneumonia and bacteraemia caused by

TABLE II-PNEUMONIA OR BACTERAEMIA IN ELDERLY PATIENTS, NEW YORK, 1937-43*

\begin{tabular}{|c|c|c|c|c|}
\hline- & $\begin{array}{l}\text { Vaccinees } \\
(\mathrm{n}=5750)\end{array}$ & $\begin{array}{c}\text { Controls } \\
(\mathrm{n}=5153)\end{array}$ & $\begin{array}{c}\% \\
\text { Difference }\end{array}$ & $\mathrm{p}$ \\
\hline $\begin{array}{l}\text { Pneumonia with vaccine } \\
\text { serotype pneumococci }\end{array}$ & 3 & 33 & 92 & $p<0.001+$ \\
\hline $\begin{array}{l}\text { Bacteraemia with vaccine } \\
\text { serotype pneumococci }\end{array}$ & 1 & 12 & 93 & \\
\hline $\begin{array}{l}\text { Pneumonia with non-vaccine } \\
\text { serotype pneumococci }\end{array}$ & 31 & 63 & 56 & $p<0.001+$ \\
\hline $\begin{array}{l}\text { Bacteraemia with non-vaccine } \\
\text { serotype pneumococci }\end{array}$ & 7 & 22 & 71 & $\mathbf{p}<0.01 \mathrm{t}$ \\
\hline $\begin{array}{l}\text { Pneumonia with organisms } \\
\text { other than pneumococci }\end{array}$ & 65 & 131 & 56 & $p<0.001+$ \\
\hline
\end{tabular}

*Adapted from Kaufman.

†Calculated by chi-square. $\$$ Calculated by Fisher's exact test, two-tailed.

non-vaccine types and pneumonia not thought to be caused by pneumococcus. Although not explicable on present knowledge, administration of pneumococcal vaccine may, under some circumstances, have a protective effect that extends beyond disease caused by vaccine types.

Infectious Disease Section,

Department of Medicine,

V. A. Medical Center

and University of Minnesota

Minneapolis, Minnesota 55417, U.S.A.

GREGORY A. FILICE

\section{DEXAMETHASONE SUPPRESSION TEST IN DEPRESSION}

SIR,-Dr Holsboer and colleagues (Sept. 27, p. 706) have had less encouraging experience than others with the dexamethasone suppression test (DST) in the diagnosis of depression. The DST results were only moderately consistent with clinical diagnostic assessments and an abnormal DST had a predictive value of $70 \%$ for the diagnosis of endogenous depression. In nine other studies from eight centres on a total of 1021 patients a much better diagnostic performance of the DST has been recorded. ${ }^{2}$ Abnormal DST results were found in $47 \%$ of 514 patients with endogenous or primary depression (sensitivity), whereas $97 \%$ of 507 patients with other psychiatric diagnoses had normal DST results (specificity). Thus the diagnostic confidence or predictive value of an abnormal DST result for endogenous depression would be $93 \%$. A standard-

1. Kaufman P. Pneumonia in old age: Active immunization against pneumona with pneumococcus polysaccharide: Results of a six-year study. Arch Intern Med 1947, 79: $518-31$

2. Carroll BJ: The dexamethasone suppression test for melanchoha. $\operatorname{Br} \mathcal{F}$ Psychiat (in press). ised DST has now been developed ${ }^{3}$ which gives improved sensitivity $(67 \%)$ while retaining a high specificity $(96 \%)$.

The more important lesson from Holsboer's report is that, as your editorial (Oct. 4, p. 730) put it, "traditional (clinical) skills have their limitations" so that an objective measure like the DST may help us to identify discrepancies in diagnostic practice between different centres. If different investigators find widely differing frequencies of abnormal DST results among their patients, even though they may believe they are using identical criteria for their diagnoses, then they indeed are not studying comparable groups of patients. Similar$l y$, if some investigators begin to find a high frequency of abnormal DST results among depressed patients whom they regard as nonendogenous, then this may serve as a signal that their diagnostic practice differs from that of most other workers.

As more groups begin to use the DST we may expect that a consensus about its diagnostic value in psychiatry will emerge. All we can say for the present is that we are moving towards a redefinition of "endogenous depression". This redefinition will aim to include the new biological markers and to give them diagnostic weightings along with the traditional clinical features. This process is exactly analogous to that by which specific disease concepts have developed in other areas of medicine. We now have biological evidence to support the isolation of endogenous depression as a separate disorder apart from the undifferentiated, heterogeneous group of conditions termed major depressive disorder.

The DST and other objective tests ${ }^{4}$ may become particularly useful for the asessment of patients with non-classical variants of endogenous depression such as young children, adolescents, elderly patients with pseudodementia, catatonic depressives, schizoaffective depressives, and patients with confusing clinical features such as a superimposed severe character disorder. ${ }^{2}$ some instructive surprises may be in store for clinicians as they begin to match their clinical judgment against the results of the objective diagnostic tests.

Adult Psychiatric Service,

Department of Psychiatry,

University of Michigan,

Ann Arbor, Michigan 48109, U.S.A.

Bernard J. CARroll

\section{LITHUM CARBONATE IN HAEMATOLOGY}

SrR,-Dr Bandini and colleagues (Oct. 25, p. 926) suggest that lithium carbonate is of value in limiting the severity and duration of neutropenia during remission induction therapy in adult acute lymphoblastic leukaemia. This may well be so but I feel it begs the question. Neutropenia in leukaemia induction therapy is primarily of importance because of susceptibility to infection. Whilst lithium may reduce the severity and duration of neutropenia, its ability to reduce the incidence of infection in remission induction has yet to be proved. In a report of the use of lithium therapy in the treatment of acute myelogenous leukaemia, the duration and severity of neutropenia was significantly reduced in the lithium-treated group compared with controls, but the incidence of infection was not. ${ }^{5}$ Indeed, lithium may inhibit the functional integrity of granulocytes in vitro. ${ }^{6}$ Bandini did not mention infective episodes. The value of raising the neutrophil count whilst inhibiting phagocytic function has to be carefully considered. Until controlled prospective trials have been done, the role of lithium therapy in leukaemia remission induction must remain uncertain.

Medical Research Department,

Kanematsu Memorial Institute,

Sydney Hospital,

Sydney, New South Wales,

Australia

G. A. R. YounG

3. Carroll BJ, Feınberg M, Greden JF, et al. A specific laboratory test for the diagnosis of melancholia. Standardization, validation and clinical utilty. Arch Gen Psychtat (in press).

4. Carroll BJ. Implication of biological research for the diagnosis of depression. $A d v B i o l$ Psychiat (in press).

5. Stein RS, Flexner JM, Grager SE. Lithium and granulocytopenı during induction therapy of acute myelogenous leukemia. Blood 1979;54: 636-41.

6. Friedenberg WR, Marx JJ. The effect of lithium carbonate on lymphocyte, granulocyte and platelet function. Cancer 1980; 45: 91-97. 